\title{
O reformační kultuře v Lodži
}

\author{
Ivo Pospíšil (Brno)
}

Ve dnech 22.-24. 5. 2017 se v Lodži na Filologické fakultě místní univerzity konala mezinárodní konference o reformační kultuře. Možná někoho překvapí, že se konference na takové téma konala v drtivě katolickém Polsku, ale kdo zná dějiny, ví, že právě zde byla reformace poměrně silná, zejména však v částech dnešního Polska, jež tehdy k Polsku nepatřily. Hlavním garantem konference byl prof. Jarosław Płuciennik, významný polský teoretik literatury a šéfredaktor genologického časopisu Zagadnienia rodzajów literackich. Konference se zúčastnilo na 50 badatelů z celé Evropy (Velká Británie/Skotsko, USA, Německo, Polsko, Tunisko, Indonésie, Polsko a Česká republika). Nejvíce byly ovšem zastoupeny $\mathrm{v}$ podstatě všechny významnější polské univerzity; kromě pořadatelské Lodžské univerzity a Polské akademie věd např. Varšava, Gdaňsk, Krakov, obě univerzity z Lublina, Katovice, Poznaň aj.). Jazyky konference byly polština, němčina a angličtina. $Z$ početně zastoupeného Německa to byly univerzitní a jiné instituce z Rostocku, Würzburgu, Herfordu a Giessenu; z ČR to byl autor této zprávy s plenárním referátem o reformaci, protireformaci a baroku v literaturách evropského Západu a Východu. Program byl rozdělen na část plenární, kterou představovaly zvané přednášky čestných zahraničních hostí, a speciálních sekcí podle tematického zaměření. Zvláště početně zastoupena byla hudební sekce s rozsáhlým programem s vystoupeními účastníků z Polska a Německa.

$\mathrm{Na}$ počátku vystoupila s profesorskou, výrazně ideologicky zacílenou přednáškou Rita Süssmundová, poradkyně kancléřky Merklové. Skotský profesor Ian Hazlett, jenž prošel několika evropskými univerzitami, pojednal o raných proudech nábožensko-kulturní refomace, Ines Murzakuová zase přednášela o katolicko-protestantském ekumenickém dialogu; v další části plenární sekce zvaných přednášek vystoupil i autor této zprávy, dále Cora Dietlová na téma protestantské hagiografie a prof. Hans-Jürgen Bömelburg mluvil o reformačních kulturách Evropy (oba z univerzity v Giessenu). Z dalšího programu byla podstatná vystoupení Tadeusze Sznajderského o reformačním myšlení jako preludia $\mathrm{k}$ osvícenství; na téma protestantské skepse promluvila Anna Kołos, Jerzy Jastrzębski hovořil o reformaci jako projektu modernizačním i konzervativním, jiní se zabývali napřr. protestantskými kantátami, rolí židovského měštanstva ve vztahu $\mathrm{k}$ protestantské etice, osobností Adama Mickiewicze a „luteránským duchem“, žaltáři. Garant konference prof. Jarosław Płuciennik se zabýval protestantským stylem překladů žalmů. Témata byla obsažná, široká i minuciózní, v nichž se jako v kapce vody zrcadlila problematika reformace a protestantismu (sekularizace zla v Shakespearově Othellovi, reformační ženy, toruňský talmud, quakerský pacifismus, staré tisky, vztah Němců a Poláků v reformaci, v hudební sekci např. hudební teorie, polské překlady Lutherových písní, reformace v polské kultuře, hymnologie apod.

Všeobecně převládala koncepce reformace jako širokého myšlenkového procesu, jenž přesáhl dimenze náboženského hnutí a byl počátkem ideologie osvícenství, etiky kapitalismus a současně měl potenci ekumenickou, scelovací právě v době protireformačního baroka. Podstatné byly srovnávací sondy kulturologické, uměnovědné a religionistické, leč chyběl zde - právě v Polsku - hlubší pohled na roli reformace v polské společnosti, později totálně rekatolizované, a také reformace ve východní Evropě, zejména u východních Slovanů, Bělorusů, Ukrajinců, ale také Rusů, at již šlo o náboženské hnutí nebo kulturu a literaturu. Konference neměla sice slavistický ráz, ale týkala se slovanského materiálu, zejména polského a českého; citelně tu chyběla reformační problematika uherská, resp. jihoslovanská, včetně slovinské. Nicméně tak široká prezentace reformačního 
hnutí na území katolického státu, nyní ještě orientace na umění (hudba, literatura) byla přis posílenou rolí konzervativního myšlení, byla rozeně dominantní, nebot právě na této ploše sama o sobě pozoruhodná. $\mathrm{V}$ otevřené diskusi se transcendující kvality reformačního úsilí prose zde občas tolerantně střetávaly různé názory; jevovaly nejvýrazněji.

\section{prof. PhDr. Ivo Pospíšil, DrSc.}

Ústav slavistiky

Filozofická fakulta, Masarykova univerzita

Arna Nováka 1, 60200 Brno, Česká republika

ivo.pospisil@phil.muni.cz 